\title{
PENINGKATAN KETERAMPILAN MEMBACA PEMAHAMAN SISWA SEKOLAH DASAR MELALUI IMPLEMENTASI MODEL CIRC BERBANTUAN MEDIA CETAK
}

\author{
Vina Anggia Nastitie Ariawan', Niken Tri Utami' ${ }^{2}$, Rahman ${ }^{3}$ \\ ${ }^{1}$ Jurusan Pendidikan Guru Sekolah Dasar, STKIP Majenang, Indonesia \\ ${ }^{2}$ Sekolah Dasar Negeri 05, Karangpucung, Indonesia \\ ${ }^{3}$ Jurusan Pendidikan Dasar, Universitas Pendidikan Indonesia, Indonesia \\ vivianatsir@gmail.com
}

Naskah diterima: 3 Oktober, 2018, direvisi: 10 Oktober, 2018, diterbitkan: 31 Oktober, 2018

\begin{abstract}
One of effort to solve the low reading skill of students is through the implementation of innovative learning models. This research aims to enhance primary students' reading comprehenssion by implementing CIRC model within printed media. This research used collaborative action research of Kemis \& Mc Taggart model. Participants of this research were 20 students at one of primary school in Karangpucung Sub-district. Researcher employed teacher as opponent participant to implementing action research and obtain supplementary dataTechnique of collecting data used observation, interview, test, and observation and interview is used to obtain data about the implementation of research. Meanwhile, test is used to measure students' reading comprehenssion skill. Researcher analyzed data with three steps namely data reduction, displaying data, and drawing conclusion. In addition, triangulation technique is used to validating data. The research outcome showed the enhance of reading comprehenssion skill in each cycle. Based on the research outcome, researcher concludes that the implementation of CIRC model within printed media can enhance reading comprehenssion skill of primary students.
\end{abstract}

Keywords: CIRC, primary school, printed media, reading comprehenssion.

\begin{abstract}
ABSTRAK
Salah satu upaya untuk mengatasi rendahnya keterampilan membaca pemahaman siswa yaitu melalui penerapan model pembelajaran inovatif. Penelitian bertujuan untuk meningkatkan keterampilan membaca pemahaman siswa sekolah dasar melalui model CIRC berbantuan media cetak. Penelitian menggunakan penelitian tindakan kelas kolaboratif model Kemmis \& Mc Taggart. Partisipan penelitian ialah 20 siswa kelas V di salah satu sekolah dasar Kecamatan Karangpucung. Peneliti juga melibatkan guru selaku partisipan pendukung untuk mempraktikkan tindakan penelitian serta memperoleh data tambahan. Peneliti mengumpulkan data melalui teknik observasi, wawancara, dan tes. Teknik observasi dan wawancara bermanfaat untuk memperoleh data tentang keterlaksanaan penelitian. Sementara itu, teknik tes digunakan untuk mengukur keterampilan membaca pemahaman siswa. Peneliti menganalisis data melalui tiga tahap yakni mereduksi data, menyajikan data, dan menarik simpulan. Data yang telah dianalisis kemudian divalidasi melalui teknik triangulasi. Temuan penelitian menunjukkan adanya peningkatan keterampilan membaca di setiap siklus. Merujuk pada temuan penelitian, maka peneliti menyimpulkan bahwa penerapan model CIRC berbantuan media cetak dapat meningkatkan keterampilan membaca pemahaman siswa sekolah dasar.
\end{abstract}

Kata Kunci:.CIRC, media cetak, membaca pemahaman, sekolah dasar.

\section{PENDAHULUAN}

Membaca pemahaman menurut McMaster, Espin, \& van den Broek (2014) adalah proses perolehan makna secara aktif dengan melibatkan pengetahuan dan pengalaman yang dimiliki oleh pembaca serta dihubungkan dengan isi bacaan. Membaca pemahaman 
merupakan membaca dengan cara memahami materi bacaan yang melibatkan asosiasi (kaitan) yang benar antara makna dan lambang (simbol) kata, penilaian konteks makna diduga ada, pemilihan makna yang benar, organisasi gagasan ketika materi bacaan dibaca, penyimpanan gagasan, dan pemakaiannya dalam berbagai aktivitas sekarang atau mendatang (Mujiselaar \& Jong, 2015).

Membaca merupakan suatu keterampilan kompleks yang melibatkan serangkaian keterampilan yang lebih kecil lainnya. Agar siswa mampu mencapai suatu tingkat pemahaman, seharusnya ia mengalami proses yang cukup panjang. Oleh karenanya, siswa perlu mengenal dan menguasai beberapa aspek dalam membaca pemahaman. Aspek-aspek dalam membaca pemahaman meliputi (a) memahami pengertian sederhana (leksikal, gramatikal, retorikal), (b) memahami signifikansi atau makna (maksud dan tujuan pengarang relevansi/keadaan kebudayaan, reaksi pembaca), (c) evaluasi atau penilaian (isi, bentuk), (d) kecepatan membaca yang fleksibel, yang mudah disesuaikan dengan keadaan (Tarigan, 2015). Di dalam membaca pemahaman, siswa tidak hanya dituntut mengerti dan memahami isi bacaan, tetapi ia juga harus mampu menganalisis atau mengevaluasi dan mengaitkannya dengan pengalaman-pengalaman dan pengetahuan awal yang telah dimilikinya (Dalman, 2016).

Membaca memiliki kedudukan sebagai dasar untuk kemajuan dan keberhasilan dalam semua materi di sekolah, khususnya pada ranah sekolah dasar. Membaca merupakan keterampilan yang dimiliki setiap individu untuk memahami teks.Meskipun membaca berperan sebagai dasar untuk menguasai materi ajar, akan tetapi membaca merupakan salah satu isu pendidikan di Indonesia yang belum sepenuhnya terselesaikan (Rahman, dkk., 2018). Isu yang berkaitan dengan membaca yaitu rendahnya minat baca dan daya baca masyarakat di Indonesia, tidak terkecuali siswa sekolah dasar. Hal ini terbukti berdasarkan survei Rahman, Wibawa, Nirmala, \& Sakti (2018) pada siswa sekolah dasar yang mengusung Gerakan Literasi Sekolah di suatu kabupaten. Rahman, Wibawa, Nirmala, \& Sakti (2018) menemukan fakta bahwa kemampuan membaca siswa masih dikategorikan rendah, yang ditandai oleh hasil tes kecepatan membaca. Idealnya, siswa sekolah dasar memiliki kecepatan membaca $150 \mathrm{kpm}$, akan tetapi nyatanya kecepatan membaca siswa hanya $104 \mathrm{kpm}$. Kemudian, kemampuan siswa dalam penyelesaian soal membaca pemahaman mencapai $45 \%$ dan dikategorikan rendah. Selanjutnya, kemampuan literasi yang ditandai kemampuan menyimak hasil bacaan,bernalar, dan menerjemahkan isi bacaan berada pada level rendah sebesar $75 \%$ dengan tingkat pemahaman literasi pada tahap faktual literal. Hasil penelitian tersebut selaras dengan pernyataan Humairoh \& Rahman (2016) yang memaparkan bahwa rendahnya kemampuan membaca pemahaman siswa ditandai dengan banyaknya siswa yang masih belum mengerti isi dari bacaan yang dibaca, serta siswa tidak dapat menemukan kalimat utama yang ada dalam bacaan.

Merujuk pada temuan Rahman, Wibawa, Nirmala, \& Sakti (2018) maka permasalahan membaca yang selalu menjadi perbincangan terkait dengan masalah membaca pemahaman. Seperti yang telah diketahui, membaca pemahaman merupakan bagian dari keterampilan membaca atau sering sekali disebut sebagai tahap membaca lanjut. Hal ini bertemali dengan pendapat Ramadi \& Kurniawan (2014) yang memaparkan bahwa membaca pemahaman menduduki peringkat yang tinggi karena bukan sekadar memahami isi bacaan, membandingkan, dan meyakini pendapat yang tersurat dalam bacaan. Namun, membaca pemahaman merupakan kegiatan yang perlu dibina dan dikembangkan secara bertahap pada siswa sekolah dasar. Pembinaan membaca bertujuan agar kelak membaca menjadi suatu pembiasaan atau habitual. Linane (2014) menemukan setidaknya enam penyebab rendahnya penguasaan membaca pemahaman siswa yang 
terdiri dari (1) penggunaan bahasa wacana yang terlalu rumit, (2) topik wacana yang tidak sesuai karakteristik siswa, (3) teks wacana yang terlalu panjang, (4) soal evaluasi yang tidak sesuai dengan wacana atau tidak berkaitan dengan wacana, (5) rendahnya kemampuan guru memberi umpan balik pada siswa sehingga terjadi kesalahpahaman makna, (6) penyajian pembelajaran yang hanya menekankan pada konsep baca kemudian jawab pertanyaan.

Menanggapi permasalahan tersebut, peneliti merasa tertantang untuk mendapatkan jalan keluar permasalahan yang ada. Salah satu upaya untuk dapat menyelesaikan permasalahan membaca pemahaman yaitu melalui implementasi model pembelajaran inovatif dengan berbantuan media pembelajaran. Model pembelajaran yang diimplementasikan pada penelitian ini berupa model Cooperative Integrated Reading and Composition $(C I R C)$. Model CIRC merupakan model yang membantu siswa dalam pengembangan keterampilan membaca dan menulis siswa secara komprehensif. Model CIRC memberi keuntungan pada siswa untuk bekerja sama dalam pemahaman materi pembelajaran (Kartika \& Morelent, 2018). Model CIRC didefinisikan sebagai model pembelajaran kooperatif untuk membantu guru dalam peningkatan praktik pembelajaran membaca. Model CIRC diasumsikan sebagai model yang tepat dan komprehensif dalam pembelajaran menulis dan membaca (Darmayanti, 2014).

Pemilihan model CIRC berdasarkan pada hasil penelitian sebelumnya yang menerapkan model $C I R C$ terhadap keterampilan membaca pemahaman bahasa Jerman siswa sekolah menengah. Hasil penelitian yang dilakukan Fitriani \& Hasmawati (2018) mengindikasikan bahwa model $C I R C$ berpengaruh terhadap keterampilan membaca pemahaman bahasa Jerman siswa. Oleh karenanya, peneliti mencoba untuk mengatasi permasalahan membaca pemahaman siswa sekolah dasar melalui model CIRC. Selain itu, peneliti mengombinasikan model pembelajaran dengan media sebagai penunjang ketercapaian tujuan penelitian. Peneliti memilih media cetak sebagai media pendukung karena media cetak terdiri dari beragam jenis teks yang dapat menarik minat membaca siswa. Apabila jenis teks sesuai karakteristik siswa maka tidak mustahil jika keterampilan membaca pemahaman siswa meningkat.

Berdasarkan pemaparan sebelumnya, maka peneliti tertarik untuk meningkatkan keterampilan membaca pemahaman siswa melalui model $C I R C$ berbantuan media cetak. Langkah-langkah untuk mengimplementasikan model CIRC berbantuan media cetak yaitu (a) guru menyiapkan materi pembelajaran dan media cetak; (b) guru membagi siswa dalam kelompok yang beranggotakan empat siswa; (c) guru memberikan wacana bahan bacaan menggunakan media cetak; (d) siswa bersama kelompok mendiskusikan tugas berupa menemukan amanat tersirat dalam bacaan dan menjawab lembar kerja yang diberikan guru; (e) perwakilan kelompok mempresentasikan hasil diskusinya; (f) guru memberikan pemahaman serta umpan balik kepada siswa; (g) guru menyimpulkan materi pelajaran yang telah dilaksanakan. Penelitian ini bertujuan untuk meningkatkan keterampilan membaca pemahaman siswa kelas $\mathrm{V}$ melalui model CIRC berbantuan media cetak dengan menggunakan metode penelitian tindakan kelas.

\section{METODOLOGI}

Penelitian ini menggunakan metode penelitian kualitatif dengan desain penelitian tindakan kelas model Kemmis \& Mc Taggart. Penelitian tindakan kelas merupakan bentuk refleksivitas untuk mengatasi permasalahan pembelajaran di kelas melalui suatu tindakan yang dilakukan secara individual maupun kolaboratif (Cohen, Manion, \& Marison, 2011). Desain penelitian tindakan kelas model Kemmis \& Mc Taggart dikenal dengan sistem 
spiral reflektif yang terdiri dari tahap perencanaan, tindakan, observasi, dan refleksi. Penelitian tindakan kelas adalah upaya yang dilakukan untuk memperbaiki keadaan atau memecahkan masalah yang dihadapi dalam kegiatan pembelajaran (Mulyasa, 2013). Arikunto, Suhardjono, \& Supardi (2013) menjelaskan salah satu ciri khas PTK yaitu adanya kolaborasi atau kerja sama antara praktisi dan peneliti.Penelitian dilaksanakan oleh peneliti dibantu teman sejawat selaku observer, dan guru kelas V selaku praktisi. Partisipan penelitian ialah 20 siswa kelas V di salah satu sekolah dasar Desa Karangpucung, Kecamatan Karangpucung.

Adapun teknik pengumpulan data menggunakan observasi, wawancara, dan tes. Teknik observasi yaitu suatu pengumpulan data dengan mengadakan pengamatan langsung terhadap suatu subjek atau objek penelitian. Melalui observasi, peneliti langsung turun ke lapangan untuk mengamati perilaku dan aktivitas subjek di lokasi penelitian (Creswell, 2013). Observasi adalah cara pengumpulan data dengan mengadakan pencatatan terhadap hal yang menjadi sasaran pengamatan. Observasi sebagai alat pengumpul data dimanfaatkan untuk mengamati keterlaksanaan model CIRC berbantuan media cetak dalam peningkatan keterampilan membaca pemahaman. Selanjutnya, wawancara adalah kegiatan tanya jawab yang dilakukan untuk mendapatkan informasi secara lebih mendalam terkait keterlaksanaan model $C I R C$ berbantuan media cetak terhadap keterampilan membaca pemahaman siswa. Dalam penelitian kualitatif, wawancara terjadi ketika peneliti menanyakan berbagai pertanyaan yang bersifat terbuka (Creswell, 2015). Wawancara terdiri dari wawancara terstruktur dan wawancara tidak terstruktur. Peneliti menggunakan wawancara terstruktur untuk mengumpulkan data penelitian. Wawancara terstruktur adalah wawancara yang telah dipersiapkan secara matang serta pertanyaan-pertanyaan yang akan diajukan telah dipersiapkan terlebih dahulu (Azwar, 2013).

Tes digunakan untuk mengukur hasil belajar siswa setelah kegiatan pembelajaran. Sanjaya (2013) menjelaskan bahwa tes merupakan instrumen pengumpulan data untuk mengukur kemampuan kognitif atau tingkat penguasaan materi pembelajaran siswa. Penelitian ini menggunakan jenis tes tertulis bersifat uraian atau essay. Tes dilakukan untuk mengukur keterampilan membaca pemahaman siswa. Tes dilaksanakan pada akhir pembelajaran sesudah penerapan model $C I R C$ di setiap pertemuan pada setiap siklusnya. Peneliti menyusun tes keterampilan membaca pemahaman dengan kategori literal dan inferensial.

Hasil observasi, wawancara, dan tes kemudian dianalisis melalui kegiatan reduksi data, penyajian data, dan penarikan kesimpulan (Miles \& Huberman dalam Sugiyono, 2015). Reduksi data merupakan proses pemilihan, pemusatan perhatian pada penyederhanaan, pengabstrakan, dan transformasi data yang muncul dari catatan-catatan. Reduksi memberikan gambaran yang lebih jelas, sehingga dapat mempermudah peneliti untuk melakukan pengumpulan data selanjutnya. Setelah mereduksi data, peneliti menyajikan data dalam bentuk tabel, grafik, atau bagan sehingga data terorganisasikan dan mudah untuk dipahami. Data yang telah tersaji lantas ditarik suatu simpulan. Penarikan kesimpulan dilakukan untuk merefleksikan tindakan yang telah dilaksanakan sehingga dapat merencakanan tindakan selanjutnya atau menyimpulkan hasil penelitian keseluruhan (Sugiyono, 2015).

Validitas merupakan derajad ketepatan antara data yang terjadi pada objek penelitian dengan data yang dilaporkan oleh peneliti. Creswell (2015) mengungkapkan validitas dikatakan akurat apabila sesuai dengan sudut pandang peneliti, partisipan, atau pembaca. Data yang valid dapat diperoleh melalui teknik triangulasi. Sugiyono (2015) menerangkan bahwa triangulasi merupakan teknik pengumpulan data dengan 
menggabungkan berbagai teknik pengumpulan data dan sumber data yang telah ada. Triangulasi yang digunakan dalam penelitian ini yaitu triangulasi sumber dan triangulasi teknik. Peneliti menggunakan triangulasi sumber untuk memperoleh data tentang penerapan model CIRC berbantuan media cetak yang bersumber dari guru dan siswa. Sementara itu, triangulasi teknik diperoleh melalui teknik observasi, wawancara, dan tes. Keberhasilan suatu penelitian dapat diukur melalui ketercapaian indikator yang dijadikan sebagai acuan keberhasilan atau keefektifan penelitian. Implementasi model CIRC berbantuan media cetak dalam keterampilan membaca pemahaman siswa dikategorikan berhasil apabila 85\% nilai siswa memenuhi KKM yaitu 75 .

\section{HASIL DAN DISKUSI}

a. Hasil

Sebelum melaksanakan penelitian, terlebih dahulu peneliti melakukan tes pratindakan untuk mengukur keterampilan pemahaman siswa kelas V. Hasil tes keterampilan membaca pemahaman pada pratindakan tertera dalam tabel 1 .

Tabel 1. Hasil Keterampilan Membaca Pemahaman Pratindakan

\begin{tabular}{cccc}
\hline Nilai & Frekuensi & Persentase $(\%)$ & Keterangan \\
\hline 45 & 1 & 5 & Belum Tuntas \\
50 & 5 & 25 & Belum Tuntas \\
60 & 3 & 15 & Belum Tuntas \\
65 & 1 & 5 & Belum Tuntas \\
70 & 4 & 20 & Belum Tuntas \\
75 & 2 & 10 & Tuntas \\
80 & 3 & 15 & Tuntas \\
85 & 1 & 5 & \\
Jumlah siswa & 20 & 100 & \\
Rata-rata nilai & 64,75 & & \\
Jumlah siswa tuntas & 6 & 30 & \\
Jumlah siswa belum tuntas & 14 & 70 & \\
\hline
\end{tabular}

Hasil tes keterampilan membaca pemahaman siswa pratindakan dikategorikan masih rendah karena banyak siswa yang memperoleh nilai di bawah KKM. Apabila ditinjau dari tingkat membaca pemahaman, semua siswa kelas $\mathrm{V}$ masih berada pada tingkat literal. Hampir seluruh siswa kelas $\mathrm{V}$ belum mampu menjawab pertanyaan yang bersifat inferensial. Siswa hanya menjawab pertanyaan yang jawabannya tertera di dalam bacaan. Namun, ketika terdapat soal yang jawabannya tidak tertera dalam pertanyaan maka siswa kesulitan menjawab. Oleh sebab itu, keterampilan membaca pemahaman siswa masih jauh dari harapan.Setelah melaksanakan tes pratindakan, peneliti mengimplementasikan model CIRC berbantuan media cetak untuk meningkatkan keterampilan membaca pemahaman siswa. Implementasi model $C I R C$ berbantuan media cetak dilaksanakan sebanyak 3 siklus atau 6 kali pertemuan. Hasil tes keterampilan membaca pemahaman pada tiap pertemuan tertera dalam tabel 2. 
Tabel 2. Hasil Keterampilan Membaca Pemahaman Tiap Siklus

\begin{tabular}{ccccc}
\hline \multirow{2}{*}{ Siklus } & \multicolumn{2}{c}{ Pertemuan } & \multirow{2}{*}{ Rata-rata nilai } & Persentase Ketuntasan \\
\cline { 2 - 3 } & 1 & 2 & & $67,5 \%$ \\
\hline I & 71,5 & 76,75 & 74,12 & $72,5 \%$ \\
\hline II & 78 & 80 & 79 & $92,5 \%$ \\
\hline III & 81 & 85 & 83 & \\
\hline
\end{tabular}

Hasil keterampilan membaca pemahaman setelah adanya tindakan mengindikasikan suatu peningkatan pada setiap pertemuannya. Meskipun pencapaian hasil keterampilan membaca pemahaman siswa sudah melebihi batas indikator akan tetapi masih ada siswa yang belum mengalami peningkatan keterampilan membaca pemahaman. Siswa yang bersangkutan belum mencapai nilai KKM yang telah ditetapkan. Ditinjau dari tingkat membaca pemahaman, sebanyak $40 \%$ siswa sudah mencapai tingkat inferensial sedangkan $60 \%$ siswa mencapai tingkat literal. Pencapaian keterampilan membaca pemahaman bila ditinjau dari klasifikasinya belum mencapai hasil yang maksimal. Namun, bila ditinjau dari pencapaian ketuntasan hasil belajar maka keterampilan membaca pemahaman mencapai peningkatan yang hampir sempurna. Oleh karena itu, model CIRC berbantuan media cetak dapat dikatakan berhasil meningkatkan keterampilan membaca pemahaman siswa kelas $\mathrm{V}$. b. Diskusi

Ruang lingkup pembelajaran membaca di sekolah dasar berupaya untuk meningkatkan pencapaian tujuan pembelajaran yang berupa memberikan bekal pengetahuan dan kemampuan kepada siswa untuk menguasai teknik-teknik membaca dan menangkap isi bacaan dengan baik dan benar. Membaca perlu dapat perhatian baik dari guru, sekolah, orang tua, dan pemerintah karena makna belajar diciptakan pembelajar dari apa yang mereka lihat, dengar, rasakan, dan alami (Suyono \& Hariyanto, 2011). Dieu (2016) berpendapat bahwa membaca adalah proses membangun makna melalui interaksi yang dinamis antara pengetahuan yang ada pada pembaca, informasi yang disarankan oleh bahasa tertulis,dan konteks dalam situasi membaca. Membaca pemahaman melibatkan kegiatan untuk mengingat informasi dari teks, penggalian tema, terlibat lebih tinggi dalam keterampilan berpikir, membangun gambaran mental dari teks, dan memahami struktur teks. Membaca pemahaman merupakan kegiatan membaca yang dilakukan oleh individu untuk memahami isi bacaan secara menyeluruh. Membaca pemahaman dilakukan dengan menghubungkan skemata atau pengetahuan awal yang dimiliki pembaca dan pengetahuan baru yang diperoleh saat membaca, sehingga proses pemahaman terbangun secara maksimal. Membaca pemahaman merupakan proses pemerolehan makna secara aktif dengan melibatkan pengetahuan dan pengalaman yang dimiliki oleh pembaca serta dihubungkan dengan isi bacaan (Rahman, Wibawa, Nirmala, \& Sakti, 2018).

Hasil penelitian ini mengindikasikan bahwa kemampuan membaca pemahaman siswa dikategorikan literal dan inferensial. Menurut Dalman (2016) pemahaman literal adalah kemampuan memahami informasi yang dinyatakan secara eksplisit dalam teks. Pemahaman literal merupakan pemahaman tingkat paling rendah. Meskipun berada pada tingkatan paling rendah pemahaman literal tetap penting karena prasyarat bagi pemahaman yang lebih tinggi. Pemahaman inferensial adalah kemampuan memahami informasi yang dinyatakan secara tidak langsung (tersirat) dalam teks. Memahami teks secara inferensial berarti memahami apa yang diimplikasikan oleh informasi-informasi yang dinyatakan secara eksplisit dalam teks. Pembaca menggunakan informasi yang dinyatakan secara eksplisit dalam teks, latar belakang pengetahuan, dan pengalaman pribadi secara terpadu untuk membuat dugaan atau hipotesis (Dalman, 2016). 
Adapun hal yang menyebabkan ketercapaian tingkat pemahaman siswa belum maksimal disebabkan pembelajaran membaca pemahaman tidak dilakukan secara intens. Dengan demikian, pada setiap pertemuan beberapa siswa masih membutuhkan binaan dalam proses membaca pemahaman. Siswa juga tidak dibiasakan membaca secara rutin sehingga daya baca mereka belum mengindikasikan peningkatan yang maksimal. Hal ini sebagaimana penjelasan dari Logan, Medford, \& Hughes (2011) bahwa salah satu faktor untuk meningkatkan keterampilan membaca siswa yaitu motivasi yang diberikan guru. Siswa yang termotivasi akan lebih sering membaca sehingga tingkat pemahaman bacaan dan pemahaman materi yang diberikan langsung oleh guru akan semakin berkembang. Keterampilan membaca pemahaman siswa yang tinggi tentunya mempermudah penguasaan materi pembelajaran lain karena membaca pemahaman menjadi salah satu faktor keberhasilan akademik (Wolters, dkk., 2016). Sebaliknya, siswa yang tidak termotivasi membaca akan berdampak pada perkembangan kognitif yang rendah.

Model CIRC merupakan model komprehensif untuk mengajari pelajaran membaca, menulis, dan seni berbahasa pada kelas yang lebih tinggi di sekolah dasar. Pengembangan model CIRC dihasilkan dari sebuah analisis masalah-masalah tradisional dalam pengajaran pelajaran membaca, menulis, seni berbahasa (Slavin, 2008). Fokus utama dari model CIRC adalah membuat penggunaan waktu tindak lanjut menjadi lebih efektif. Siswa yang bekerja sama dalam tim-tim kooperatif dikoordinasikan dengan pengajaran kelompok membaca, supaya dapat memenuhi tujuan-tujuan dalam bidang-bidang lain seperti pemahaman membaca, kosa kata, pembacaan pesan, dan ejaan. Teknik pembelajaran menggunakan wacana/teks di mana siswa dibagi dalam bentuk berpasangan untuk membaca dan membuat ringkasan. Hal ini selaras dengan pandangan Huda (2013) yang menjelaskan bahwa dalam model $C I R C$, setiap siswa bertanggung jawab terhadap tugas kelompok. Setiap anggota kelompok saling mengeluarkan ide - ide untuk memahami suatu konsep dan menyelesaikan tugas, sehingga terbentuk pemahaman dan pengalaman belajar yang lama.

Mengenai penerapan model CIRC (Cooperative Integrated Reading and Composition). Pada tahap cooperative, yaitu dengan membagi siswa menjadi lima kelompok secara heterogen mampu mengatasi permasalahan pengelolaan kelas yang ditemukan sebelumnya. Tahap reading, yaitu dengan membaca dan mengidentifikasi ciriciri pikiran pokok terlebih dahulu mampu menjadi jembatan pemahaman awal siswa sebelum akhirnya siswa dapat menentukan pikiran pokok. Pada tahap composition, yaitu menulis paragraf dari pikiran pokok yang telah ditentukan mampu memfasilitasi siswa menuangkan pemahamannya dari pengetahuan yang ia dapat pada tahap reading. Tahapan pembelajaran CIRC ini sangat membantu siswa dalam menentukan pikiran pokok yang merupakan bagian dari pembelajaran membaca di sekolah dasar (Delviani, Djuanda, \& Hanifah, 2016).

Sebagai upaya untuk menunjang penggunaan model CIRC maka dibutuhkan media untuk mendukung siswa memahami pembelajaran. Daryanto (2010) mengungkapkan bahwa secara umum media mempunyai kegunaan seperti berikut (a) memperjelas pesan agar tidak terlalu verbalistis, (b) mengatasi keterbatasan ruang, waktu, tenaga, dan daya indra, (c) menimbulkan gairah belajar, interaksi lebih langsung antara murid dengan sumber belajar, (d) memungkinkan anak belajar mandiri sesuai dengan bakat dan kemampuan visual, auditori, dan kinestetiknya, (5) memberi rangsangan yang sama, mempersamakan pengalaman dan menimbulkan persepsi yang sama. Media yang dapat digunakan sebagai penunjang model $C I R C$ di antaranya adalah media cetak. Media cetak adalah media visual yang pembuatannya melalui proses percetakan atau offset. Media 
bahan cetak ini menyajikan pesannya melalui huruf dan gambar-gambar yang diilustrasikan untuk memperjelas pesan atau informasi yang disajikan. Contoh media cetak yaitu buku teks, modul, dan buku panduan (Susilana \& Riyana, 2007). Dalam penelitian ini, peneliti menggunakan media cetak berupa buku cerita bergambar, handout, majalah anak, dan brosur. Sejalan dengan itu, Ariawan \& Pratiwi (2017) menerangkan bahwa untuk menyajikan pembelajaran guru perlu memilih wacana yang representatif yaitu wacana yang isinya sesuai dengan karakteristik siswa serta menggugah siswa untuk terus membaca. Sumber wacana tidak hanya berasal dari buku paket tetapi dapat juga dari majalah, koran, atau hasil karya guru maupun siswa.

Mengacu pada pemaparan yang telah disampaikan maka peneliti menarik simpulan bahwa model $C I R C$ berbantuan media cetak dapat meningkatkan keterampilan membaca pemahaman siswa kelas V. Hal ini sesuai dengan penelitian sebelumnya yang dilakukan oleh Ramadi \& Kurniawan (2014) yang menerapkan model CIRC dalam peningkatan keterampilan membaca pemahaman siswa kelas V. Penelitian oleh Delviani, Djuanda, \& Hanifah (2016) juga menunjukkan hasil yang serupa bahwa model $C I R C$ berbantuan media puzzle dapat meningkatkan keterampilan membaca pemahaman anak dalam penentuan pikiran pokok.

\section{KESIMPULAN}

Membaca pemahaman sangat penting untuk keberhasilan akademik jangka panjang dan bergantung pada keterampilan bahasa yang muncul di awal kehidupan. Membaca pemahaman bertujuan untuk mencari dan memperoleh informasi mencakup isi dan memahami makna bacaan. Selain itu, tujuan membaca pemahaman adalah agar pembaca dapat memahami isi bacaan dan memberikan tanggapan terhadap bacaan tersebut. Permasalahan membaca pemahaman di Indonesia dikategorikan sebagai permasalahan yang belum terselesaikan hingga saat ini. Berbagai penyebab dari permasalahan membaca salah satunya disebabkan kurang sesuainya pembelajaran dengan karakteristik siswa. Model CIRC disinyalir menjadi salah satu model pembelajaran yang cocok untuk mengatasi permasalahan membaca pemahaman siswa. Pada penelitian ini, peneliti juga mengombinasikan penggunaan media cetak dalam pembelajaran CIRC sehingga peningkatan keterampilan membaca pemahaman siswa akan lebih optimal. Media cetak yang digunakan dalam penelitian ini berupa buku cerita bergambar, handout, brosur, dan majalah anak. Siswa mengalami peningkatan keterampilan membaca pemahaman pada setiap siklusnya. Tingkat pemahaman siswa juga mengalami hal serupa. Sebelum pelaksanaan tindakan, siswa hanya mencapai tingkat literat. Namun, setelah pelaksanaan tindakan siswa sudah mencapai tingkat inferensial. Oleh sebab itu, peneliti menarik simpulan bahwa model $C I R C$ berbantuan media cetak dapat meningkatkan keterampilan membaca pemahaman siswa kelas $\mathrm{V}$.

\section{DAFTAR PUSTAKA}

Ariawan, V.A.N., \& Pratiwi, I.M. (2017). Implementing Joyful learning Strategy Using Treasure Clue Game Method in order to Improve Reading Comprehension Skill. Jurnal Prima Edukasia, 5 (2), 203-210.

Arikunto, S., Suhardjono., \& Supardi. (2008). Penelitian Tindakan Kelas. Jakarta: Bumi Aksara.

Azwar, S. (2013). Metode Penelitian. Yogyakarta: Pustaka Pelajar.

Cohen, L., Manion, L., \& Marrison, K. (2011). Research in Education Sixth Edition. Newyork: Routledge. 
Creswell, J.W. (2013). Research Design: Pendekatan Kualitatif, Kuantitatif, dan Mixed. Yogyakarta: Pustaka Pelajar. Penerjemah Sutjipto.

Creswell, J.W. (2015). Riset Pendidikan Perencanaan, Pelaksanaan, dan Evaluasi Riset Kualitatif dan Kuantitatif Edisi Kelima. Yogyakarta: Pustaka Pelajar. Penerjemah Sutjipto.

Dalman. (2016). Keterampilan Membaca. Jakarta: Grafindo Persada.

Darmayanti. (2014). The Implementation of Cooperative Integrated Reading and Composition (CIRC) Method in Teaching Narrative Text to Improve Students' Reading Comprehension at The Eleventh Grade Students of MAN 2 Model Makassar. Ethical Lingua Journal, 1 (2),

Daryanto. (2010). Media Pembelajaran. Bandung: Alfabeta.

Delviani, D., Djuanda, D., \& Hanifah, N. (2016). Penerapan Model Kooperatif Tipe CIRC (Cooperative Integrated Reading and Composition) Berbantuan Media Puzzle Kalimat untuk Meningkatkan Kemampuan Membaca Anak dalam Menentukan Pikiran Pokok. Jurnal Pena Ilmiah, 1 (1), 91-100.

Dieu,T.T.T. (2016). Trying $K-W-L$ Strategy on Teaching Reading Comprehension to Passive Students in Vietnam. International Journal of Language and Linguistics, 3 (6), 481-492.

Fitriani \& Hasmawati. (2018). Model Pembelajaran Cooperative Integrated Reading and Composition (CIRC) dalam Meningkatkan Kemampuan Membaca Memahami Bahasa Jerman Siswa. Indonesian Journal of Educational Studies, 21 (1), 77-85.

Huda, M. (2013). Cooperative Learning. Yogyakarta: Pustaka Pelajar.

Humairoh, S., \& Rahman. (2016). Pengaruh Model Cooperative Integrated Reading and Composition (CIRC) dan Cooperative Script (CS) terhadap Kemampuan Membaca Pemahaman Siswa Sekolah Dasar. Metodik Didaktik, 11 (1), 8-20.

Kartika, D., \& Morelent, Y. (2018). The Influence of the CIRC and TTW Learning Model and Learning Motivation toward Grade 8 Students' Report Writing Skills at SMP Muhammadiyah Padang. Theory and Practice in Language Studies, 8 (3), 278-284.

Linane, MJ. (2014). 6 Reading Comprehension Problems and What To Do About Them. Retrieved from http://www.coolcatteacher.com.

Logan, S., Medford, E., \& Hughes, N. (2011). The Importance of Intrinsic Motivation for High and Low Ability Readers' Reading Comprehension Performance. Learning and Individual Differences, 21, 124-128.

McMaster, K. L., Espin, C. A., \& van den Broek, P. (2014). Making connections: Linking Cognitive Psychology and Intervention Research to Improve Comprehension of Struggling Readers. Learning Disabilities Research and Practice, 29, 17-24.

Mujiselaar, M. M. L., \& de Jong, P. F. (2015). The Effects of Updating Ability and Knowledge Reading Strategies on Reading Comprehension. Learning and Individual Differences, 43,111-117.

Mulyasa, E. (2013). Praktik Penelitian Tindakan Kelas. Bandung: Remaja Rosdakarya.

Rahman, dkk. (2018). Pop-Up Book in Reading Comprehension Ability Context in Thematic Learning. Yogyakarta: Universitas Negeri Yogyakarta.

Rahman, Wibawa, S., Nirmala, S.D., \& Sakti, A.W. (2018). Kemampuan Literasi Siswa dalam Pembelajaran Membaca Pemahaman melalui Model Guided Reading. Bandung: Universitas Pendidikan Indonesia.

Ramadi, \& Kurniawan, H. (2014). Meningkatkan Keterampilan Membaca Pemahaman Dengan Menggunakan Model Cooperative Integrated Reading and Composition (CIRC) Dikombinasi dengan Numbered Heads Together (NHT) Siswa Kelas V SDN Tatah Pemangkih Laut 1 Kabupaten Banjar. Jurnal Paradigma, 9 (2), 25-30.

Sanjaya, W. (2013). Penelitian Tindakan Kelas. Jakarta: Kencana Prenada Media Group. Slavin, R. (2008). Cooperative Learning-Teori, Riset dan Praktik. Bandung: Nusa Media. Sugiyono. (2015). Metode Penelitian Kuantitatif Kualitatif dan R\&D. Bandung: Alfabeta. Susilana, R. \& Riyana, C. (2007). Media Pembelajaran. Bandung: CV Wacana Prima. Suyono \& Hariyanto. (2011). Belajar dan Pembelajaran. Bandung: Rosda.

Tarigan (2015). Membaca Sebagai Suatu Keterampilan Berbahasa. Bandung: Angkasa. 
Wolters, C.A., dkk. (2016). Examining a Motivational Treatment and Its Impact on Adolescents' Reading Comprehension and Fluency. The Journal of Educational Research, 1, 1-13. 